\title{
Joel Feinberg for Neophytes
}

\section{Burgess-Jackson $\mathrm{K}^{*}$}

The University of Texas at Arlington, USA

*Corresponding author: Keith Burgess-Jackson, J.D., Ph.D., Associate Professor of Philosophy, Department of Philosophy and Humanities, College of Liberal Arts, The University of Texas at Arlington, Box 19527, Arlington, Texas, 76019-0527, USA, Email: kbj4@att.net, kbj@uta.edu

\section{Conceptual Paper}

Volume 3 Issue 4

Received Date: October 28, 2020

Published Date: November 09, 2020

DOI: $10.23880 /$ phij-16000158

\section{Abstract}

Joel Feinberg (1926-2004) was a major figure in 20th-century philosophy. He made signal contributions to two distinct disciplines: normative jurisprudence (i.e., positive law as it ought to be) and descriptive or analytic ethics (i.e., positive morality as it is). The aim of this essay is to introduce Feinberg to a new generation of scholars, some of whom may be unfamiliar with his work, but all of whom-whether in law, social science, or the humanities-stand to benefit from it. The essay traces Feinberg's career path, provides a synopsis of his 10 monographs, and discusses (briefly) his liberalism.

Keyword: Joel Feinberg (1926-2004); Philosophy; Philosophy of law; Legal philosophy; Moral philosophy; Ethics; Social philosophy; Political philosophy; Law; Criminal law; Jurisprudence; Liberalism

\section{Professional Career}

Joel Feinberg was an American moral, social, legal, and political philosopher. He was born in Detroit, Michigan, on 19 October 1926, the son of Abraham Joel Feinberg and Marion Feinberg (née Tahl). After attending the University of Illinois in 1944, he participated in the United States Army's Officer Training Program in Chicago for two years. At the conclusion of World War II, he enrolled at the University of Michigan in Ann Arbor, where he earned bachelor's (1949), master's (1951), and doctoral (1957) degrees. His formal education culminated with a dissertation (directed by Charles L. Stevenson) entitled "Naturalism and Liberalism in the Philosophy of Ralph Barton Perry." (Perry had been Stevenson's dissertation director.)

During his nearly four-decade teaching career, Feinberg had regular academic appointments at Brown University (1955-1962), Princeton University (1962-1966), UCLA (1966-1967), Rockefeller University (1967-1977, including a six-year stint as Chair of the Department of Philosophy), and the University of Arizona (1977-1994, including a fouryear stint as Head of the Department of Philosophy). He had visiting appointments at Colorado, Michigan, Calgary, Columbia, Princeton, and New York Universities. When he retired from the University of Arizona in 1994, he had attained the rank of Regents Professor of Philosophy and Law. Regents Professor is the highest faculty rank at the University of Arizona. It is reserved for "full professors with exceptional achievements that have brought them national or international recognition."

Feinberg was the recipient of many fellowships, awards, honors, and prizes during his career. Besides being a Fellow of the prestigious American Academy of Arts and Sciences, he was Fellow of the Center for Advanced Study in the Behavioral Sciences at Stanford University (1960-1961), Liberal Arts Fellow at Harvard Law School (1963-1964), Guggenheim Fellow (1974-1975), National Endowment for the Humanities Fellow (1977), Rockefeller Foundation Fellow (1981-1982), Fulbright Lecturer at Doshisha University in Kyoto, Japan (1987), Recipient of the Fred Berger Memorial Prize for Best Essay in Philosophy of Law in the Preceding Two-Year Period (1989), Romanell Phi Beta Kappa Lecturer at the University of Arizona (1990), David Ross Boyd Lecturer at the University of Oklahoma (1991), and Herbert 


\section{Philosophy International Journal}

Hart Lecturer on Jurisprudence and Moral Philosophy at University College, Oxford (1991).

Feinberg held a number of professional offices, including Editor of Prentice-Hall's Foundations of Philosophy Series, Editor of Dickenson Publishing Company's Dickenson Series in Philosophy, Board Member of the Council for Philosophical Studies (1973-1978), Member of the Advisory Board of the Center for the Study of Values (1977-1982), Vice-President of the Pacific Division of the American Philosophical Association (1980-1981), President of the Pacific Division of the American Philosophical Association (1981-1982), Chairman of the Board of Officers of the American Philosophical Association (1986-1989), and President of the American Society for Political and Legal Philosophy (19891992). He has been honored with at least three festschriften: Jules L. Coleman and Allen Buchanan, eds., In Harm's Way: Essays in Honor of Joel Feinberg (Cambridge: Cambridge University Press, 1994); a special issue of Arizona Law Review 37 (spring 1995): 1-353; and a special double issue of The Journal of Ethics 10 (January 2006): 1-204.

Feinberg died in Tucson, Arizona, on 29 March 2004, at the age of 77, leaving behind his wife of 48 years, Betty (née Sowers) (to whom all four volumes of Feinberg's The Moral Limits of the Criminal Law are dedicated), and two grown children, Melissa and Benjamin.

\section{Publications}

Although a prolific writer, Feinberg's first professional publication ("On Justifying Legal Punishment") appeared somewhat late: in 1960, when he was 33 years old. He was the author of 10 books over a period of 33 years (1970 to 2003). Four of these books are collections of previously published essays (with the occasional unpublished essay included). The range of Feinberg's interests and competence are indicated by the subtitles of these collections: "Essays in the Theory of Responsibility" (1970), "Essays in Social Philosophy" (1980), "Philosophical Essays" (1992), and "Essays in Legal and Political Theory" (2003). The other six books, which will be discussed at greater length below, are sustained treatments of particular topics.

In addition to the 10 monographs, Feinberg edited or coedited six books, some of which appeared in multiple editions and some of which are still in print as of 2020. The edited volumes, in chronological order of first publication, are Reason and Responsibility: Readings in Some Basic Problems of Philosophy (1965); Moral Concepts (1969); The Problem of Abortion (1973); Philosophy of Law (with Hyman Gross) (1975); Moral Philosophy: Classic Texts and Contemporary Problems (with Henry West) (1977); and Philosophy and the Human Condition (with Tom L. Beauchamp and William T. Blackstone) (1980). Feinberg's introductions to these volumes (and to various sections thereof) are themselves significant pieces of philosophy. In addition to his 16 authored or edited books, Feinberg wrote many articles, book chapters, and reviews.

To understand the nature and scope of Feinberg's philosophical work, it will be helpful to recall two distinctions made by the 19th-century legal philosopher John Austin (1790-1859). The first is between positive law (the law as laid down by human authorities) and positive morality (the morality that happens to obtain in a given society). The second is between what is (descriptive or analytic) and what ought to be (normative). This gives rise to four disciplines or "sciences," the second and fourth of which constitute what Austin and his friend Jeremy Bentham (1748-1832) called "ethics," and which form the subject matter of Bentham's classic work An Introduction to the Principles of Morals and Legislation (1789):

- Positive law as it is (which Austin called "jurisprudence," and which today would be called descriptive or analytic jurisprudence).

- Positive law as it ought to be (which Austin and Bentham called "legislation," and which today would be called normative jurisprudence).

- Positive morality as it is (which would today be called descriptive or analytic ethics).

- Positive morality as it ought to be (which Austin and Bentham called "morals," and which today would be called normative ethics).

Feinberg worked in all four disciplines, but he made his most significant contributions to the second (normative jurisprudence) and third (descriptive or analytic ethics). What follows is a synopsis of Feinberg's 10 monographs:

1. Doing and Deserving: Essays in the Theory of Responsibility (Princeton: Princeton University Press, 1970): This book collects essays published between 1960 and 1969 (inclusive). Each essay "deals with some aspect of the complex situation in which persons intentionally, negligently, or faultlessly cause harm or benefit to others and are therefore said to deserve such responses from others as praise or blame, punishment, and legal pressure to make compensation" (vii). Feinberg thought of these essays as "straddl[ing] ethics, philosophy of mind, and philosophy of law" (ibid.). If any of the book's essays stands out from the others, it is "Justice and Personal Desert" (first published in 1963), in which Feinberg analyzes the concept of personal desert in order to "illuminate" its connection to justice. This emphasis on conceptual analysis is characteristic of 


\section{Philosophy International Journal}

Feinberg's work. As he later put it, "Conceptual clarification is the most distinctively philosophical of enterprises" (Harm to Others, 17).

2. Social Philosophy (Englewood Cliffs, NJ: PrenticeHall, 1973): This highly regarded monograph (which is still in print in its original edition nearly half a century after publication) concerns itself with "philosophical questions about social relations" (1). It lies at the intersection of analytic ethics and normative jurisprudence. Among the concepts investigated in the book's seven chapters are freedom, coercion, equality, harm, benefit, legal rights, human rights, and social justice. This is the book in which Feinberg introduced the concept of a liberty-limiting principle, which figures so prominently in his more mature work in normative jurisprudence.

3. Rights, Justice, and the Bounds of Liberty: Essays in Social Philosophy (Princeton: Princeton University Press, 1980): This book collects essays published between 1964 and 1978 (inclusive). The essays concern such concepts as liberty, harm, offense, legal paternalism, rights, and what Feinberg called "noncomparative justice." Feinberg thought of these essays as dealing with "hard cases for the application of the concept of a right" (back cover). One of the essays is remarkable for its anticipation of what came to be known as the animal-rights or animal-liberation movement-a movement that has been led by philosophers such as Peter Singer and Tom Regan. In February 1971, at a philosophical conference at the University of Georgia, Feinberg presented an essay entitled "The Rights of Animals and Unborn Generations." In this essay, Feinberg argued that there is no conceptual barrier to the possession of rights by nonhuman animals. "[M]ost of us," he writes, "do believe that animals have rights, but are reluctant to say so because of the conceptual confusions about the notion of a right that I have attempted to dispel" (166-7). Feinberg was one of the first English-speaking academic philosophers to take the idea of animal rights seriously, and perhaps the first to argue for, or at least lay the philosophical groundwork for, animal rights. (Roslind Godlovitch published an essay entitled "Animals and Morals" in January 1971, but it is unlikely that Feinberg had read it-or even heard of it-when he presented his essay a month later. Feinberg acknowledges that, "Well after the publication of [his essay], [he] learned that the essentials of [his] view were anticipated by the German philosopher Leonard Nelson in his A System of Ethics [sic; should be System of Ethics], first published in 1926" [xi].)

4. Harm to Others (New York: Oxford University Press, 1984): This is the first volume of Feinberg's fourvolume "account of the moral constraints on legislative action" (4), which he entitles The Moral Limits of the Criminal Law. In this volume, Feinberg discusses (a) the concept of harm; (b) the relation between the concept of harm and such allied concepts as interests, wants, hurts, offenses, rights, and consent; (c) hard cases for application of the concept of harm; and (d) various problems involved in assessing, comparing, and imputing harms. I will discuss the tetralogy as a whole upon completing this synopsis of Feinberg's 10 monographs.

5. Offense to Others (New York: Oxford University Press, 1985): This is the second volume of The Moral Limits of the Criminal Law. In this volume, Feinberg discusses the concept of offense (understood as a mental state distinct from harm) and some of its applications, including pornography, obscenity, and "dirty words" (191).

6. Harm to Self (New York: Oxford University Press, 1986): This is the third volume of The Moral Limits of the Criminal Law. In this volume, Feinberg discusses legal paternalism, personal autonomy, and the concept of voluntariness.

7. Harmless Wrongdoing (New York: Oxford University Press, 1988): This is the fourth and final volume of The Moral Limits of the Criminal Law. In this volume, Feinberg discusses legal moralism, which is the view that "[i]t can be morally legitimate to prohibit conduct on the ground that it is inherently immoral, even though it causes neither harm nor offense to the actor or to others" (xix-xx).

8. Freedom and Fulfillment: Philosophical Essays (Princeton: Princeton University Press, 1992): This book collects essays published between 1975 and 1991 (inclusive). The essays concern such concepts as wrongful life, abortion, freedom of expression, bad samaritanism, moral rights, and absurd self-fulfillment. The title is somewhat misleading, in that Feinberg thought of these essays as dealing with "problems about rights" (vii). The essay on abortion, which is an exemplar of practical (as opposed to theoretical) normative ethics, is a revised version of an essay published in 1979 in an anthology for students. It shows Feinberg at his philosophical best: not trying to indoctrinate impressionable readers or add to the "shrill sloganeering and propagandistic rhetoric one encounters in the political forum and in 'letters to the editor' columns of newspapers," but "lin[ing] up the critical arguments and counterarguments on both sides, expos[ing] hidden difficulties, and align[ing] the strengths and weaknesses of opposed positions, thereby showing the student how sensible and useful philosophical discussions are" (viii).

9. Doing Philosophy: A Guide to the Writing of Philosophy Papers (Belmont, CA: Wadsworth Publishing Company, 1997): Feinberg was perspicuous as well as perspicacious. His essays on even the most complicated and difficult subjects were clear, concise, penetrating, and stylish, which makes them a joy to read. Late in his career, he shared some of his vast knowledge about the craft of writing in the form of a "booklet" that, as he writes in his Preface, "is intended to help college students who are enrolled in 


\section{Philosophy International Journal}

introductory courses in philosophy and are required to write at least one philosophical paper" (vi). The book's 11 chapters cover everything from selecting a topic to plagiarism to grading criteria to principles of good writing to mistakes of grammar and diction to logic and language to informal fallacies.

10. Problems at the Roots of Law: Essays in Legal and Political Theory (New York: Oxford University Press, 2003): This book, the fourth (and final) of its type, collects essays published between 1992 and 2003 (inclusive). The essays concern such concepts as natural law, moral rights, entrapment, criminal attempts, government subsidies for the arts, and evil. As the title implies, Feinberg thought of these essays as dealing with "basic questions" (vii) in the philosophy of law. The first essay of the collection, entitled "Natural Law: The Dilemmas of Judges Who Must Interpret Immoral Laws," is Feinberg's contribution to the classic philosophical debate concerning the nature of law, which falls under the rubric of analytic jurisprudence. The question Feinberg poses for himself in this essay is what difference it makes, if any, whether legal positivism or natural-law theory is the correct account of the nature of law. Feinberg issues a split decision: with regard to "the private citizen's moral obligation to obey the law," the differences between the theories "do not amount to much" (25); but "the judge's moral obligations might be importantly different depending on whether he [or she] is a positivist or a natural law theorist" (ibid.; italics in original). Feinberg explores the latter topic (concerning the judge's obligations) in a delightful 10page dialogue between a hypothetical legal positivist and a hypothetical "theorist of natural law" (25).

\section{Liberalism}

All of Feinberg's writings were animated and informed by his liberalism, understood as a political ideology that exalts the individual, who is held to be the possessor of various rights, including robust rights to liberty and autonomy. During the 1980s, Feinberg wrote his magnum opus, the fourvolume, 1,397-page Moral Limits of the Criminal Law. His aim in this tetralogy (as he referred to it) was "to make the best possible case for liberalism" with respect to the moral limits of the criminal law (Harm to Others, 15). He thought of himself as "vindicat[ing] the traditional liberalism derived from [John Stuart] Mill's On Liberty [1859]" (ibid.).

Although Feinberg had no legal credentials-other than having been a Liberal Arts Fellow at Harvard Law School in 1963-1964-he has already influenced American law. At least one state supreme court has cited him as a persuasive authority. (See Armstrong v. Montana, 296 Mont. 361, 989 P.2d 364 [1999] [holding that a Montana statute prohibiting physician assistants from performing abortions violated the privacy, equal-protection, and bill-of-attainder provisions of the Montana constitution].)

Feinberg begins his tetralogy with what he calls a presumption in favor of (individual) liberty. (Liberty is understood negatively, as "the absence of legal coercion" [Harm to Others, 7].) This presumption means that "[l]iberty should be the norm; coercion always needs some special justification" (ibid., 9). He then sketches a number of "libertylimiting principles" (also known as "coercion-legitimizing principles"), each of which states a reason-though not a necessary or a sufficient condition-for coercing individuals. The question he sets for himself is which of these principles, if any, are valid. Here, for example, is the harm principle:

It is always a good reason in support of penal legislation that it would probably be effective in preventing (eliminating, reducing) harm to persons other than the actor (the one prohibited from acting) and there is probably no other means that is equally effective at no greater cost to other values (ibid., 26 [italics in original]).

Feinberg endorses two liberty-limiting principles: the harm principle (which is short for "harm to others principle") and the offense principle. He rejects two others: legal paternalism and legal moralism. Volume one of his tetralogy, Harm to Others, elaborates and defends the harm principle. Volume two, Offense to Others, elaborates and defends the offense principle. Volume three, Harm to Self, elaborates and rejects legal paternalism. Volume four, Harmless Wrongdoing, elaborates and rejects legal moralism.

Legislators who are guided by Feinberg's liberalism, with its normative commitments to individual liberty and personal autonomy, would prohibit and punish only harmful or seriously offensive conduct (but not necessarily all such conduct). An example of seriously offensive conduct would be a pornographic billboard that individuals cannot reasonably avoid seeing. Feinbergian (i.e., ideal) legislators would not punish conduct solely on the ground that it is harmful (or threatens harm) to the actor. That is legal paternalism. Nor would they punish conduct solely on the ground that it is immoral. That is legal moralism. Both legal paternalism and legal moralism are affronts to individual liberty as well as to personal autonomy.

It is important to understand that Feinberg's rejection of legal moralism does not rest on moral skepticism, nihilism, relativism, or subjectivism. One can be a moral objectivist-a believer in objective moral values-and still hold that it is improper for legislators to enforce the one true morality. Feinberg's aim is ultimately practical: to "guide the legislator by locating the moral constraints that limit his [or her] 
Philosophy International Journal

options" (ibid., 4). It is "a quest not for useful policies but for valid principles" (ibid.).

The four volumes together make a powerful case for what Feinberg calls "the liberal position" (ibid., 26) on the moral limits of the criminal law. He does not argue for liberalism directly, by appealing to "moral primitives" or "self-evident truths" (ibid., 17). Instead, he adopts the argumentum ad hominem technique. This consists in appealing to values, beliefs, and convictions that his readers are presumed already to have, or to judgments that they are presumed already to make (or be willing to make). (As John Locke put it, "A third way [to persuade] is, to press a Man with Consequences drawn from his own Principles, or Concessions. This is already known under the Name of Argumentum ad Hominem" [An Essay Concerning Human Understanding, book IV, chap. XVII, sec. 21 (1689)].)

Feinberg's objective in the tetralogy is to persuade his readers that the liberal position on the moral limits of the criminal law systematizes their values, beliefs, convictions, principles, and judgments better than any alternative. It is a search for coherence, not foundations. In effect, he is trying to show his readers that they are-already, unwittinglyliberals.

\section{Conclusion}

Many years ago, Daniel Dennett compiled a "philosophical lexicon" to poke fun at some of his colleagues. Here is his entry on Feinberg:

feinberg, n. A mountain of finely grained distinctions; hence feinberg, v. To work one's way out of a corner by building and mounting a feinberg. "I was pinned in my argument, but then managed to feinberg my way out." (Daniel Dennett and Asbjørn Steglich-Petersen, The Philosophical Lexicon, 2008 edition, online)

Anyone who has read Feinberg-and especially anyone who was lucky enough to have had him as an instructor-can appreciate the aptness of this entry. There is no doubt that Joel himself, who had an impish sense of humor, got a chuckle (or two) out of it.

\section{Acknowledgments}

This essay is dedicated to the memory of Joel Feinberg (1926-2004): teacher, mentor, correspondent, friend, fellow Michigander. 